\title{
Life on the Texas Range
}

Number Fourteen The M. K. Brown Range Life Series 
THIS PAGE INTENTIONALLY LEFT BLANK 
The prints reproduced in this book were made in 1936

by Erwin E. Smith for the Texas Centennial celebration and are in the collection of the Texas Memorial Museum,

University of Texas, Austin.

The publishers wish to thank the Amon Carter Museum, Fort Worth, Texas, which oversees the Erwin E. Smith Archives.

The Archives, a generous gift of Mrs. Mary Alice Pettis

which includes Smith's negatives, albums of prints, and library,

is devoted to the study of the cowboy and the open range. 


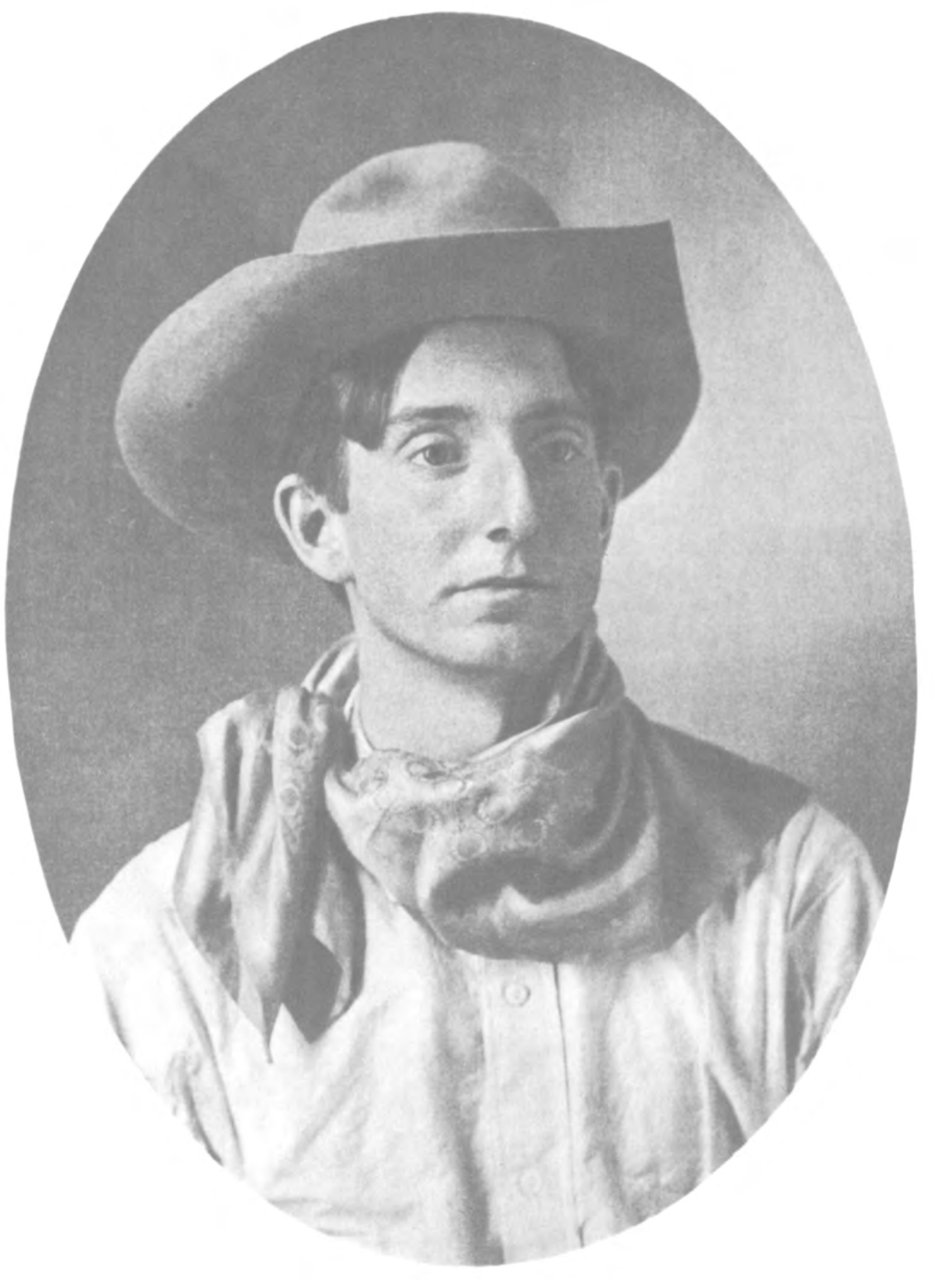

ERWIN E. SMITH 


\section{Life on the \\ Texas Range}

Photographs by Erwin E. Smith

Text by J. Evetts Haley

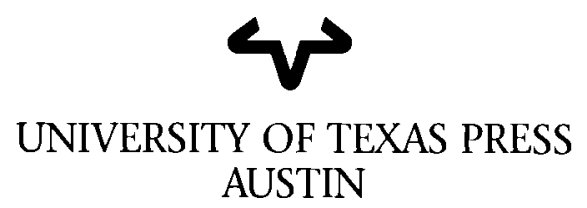




\section{NUMBER FOURTEEN}

THE M. K. BROWN RANGE LIFE SERIES

All reproduction rights to the photographs by Erwin E. Smith are held by the Amon Carter Museum, Fort Worth, Texas. The photographs may not be reproduced without prior permission from the Museum.

Cover image only, reproduced from the original negative in The Erwin E. Smith Collection of the Library of Congress on deposit at the Amon Carter Museum, Fort Worth, Texas.

International Standard Book Number 0-292-77683-7

Library of Congress Catalog Card Number 52-13181

Copyright $\mathbb{C} 1952$ by the University of Texas Press,

Renewed 1980

All Rights Reserved

Manufactured in the United States of America

Paperback Reissued, 1994

ISBN 978-0-292-74861-3 (e-book)

ISBN 978-0-292-78849-7 (individual e-book) 